\title{
Correction to: Mathematical Basis of Predicting Dominant Function in Protein Sequences by a Generic HMM-ANN Algorithm
}

\author{
Siddhartha Kundu ${ }^{1,2}$ (D) \\ Published online: 8 May 2020 \\ (c) Springer Nature B.V. 2020
}

\section{Correction to: Acta Biotheor (2018) 66:135-148 \\ https://doi.org/10.1007/s10441-018-9327-x}

The article Mathematical Basis of Predicting Dominant Function in Protein Sequences by a Generic HMM-ANN Algorithm, written by Siddhartha Kundu1, was originally published electronically on the publisher's internet portal on 26 April 2018 without open access. With the author(s)' decision to opt for Open Choice the copyright of the article changed on 1 May 2020 to (C) The Author(s) 2020 and the article is forthwith distributed under a Creative Commons Attribution 4.0 International License (https://creativecommons.org/licenses/by/4.0/), which permits use, sharing, adaptation, distribution and reproduction in any medium or format, as long as you give appropriate credit to the original author(s) and the source, provide a link to the Creative Commons licence, and indicate if changes were made.

The original article has been corrected.

Publisher's Note Springer Nature remains neutral with regard to jurisdictional claims in published maps and institutional affiliations.

The original article can be found online at https://doi.org/10.1007/s10441-018-9327-x.

Siddhartha Kundu

siddhartha_kundu@yahoo.co.in

1 Department of Biochemistry, Dr. Baba Saheb Ambedkar Medical College and Hospital, Government of NCT of Delhi, Sector - 6, Rohini, Delhi 110085, India

2 School of Computational and Integrative Sciences, Jawaharlal Nehru University, New Mehrauli Road, New Delhi 110067, India 